\title{
Frontal Sinus Variations and Prevalence of Frontal Recess Cells among Adult Egyptians: Computerized Tomography Study
}

\author{
ABDEL-FATTAH H. AL-EBIARY, M.D.; GAMAL H. MOHAMMED, M.D.; HADEEL S. EMAM, M.Sc. and \\ REDA A. IMAM, M.D.
}

The Department of Anatomy \& Embryology, Faculty of Medicine, Cairo University

\begin{abstract}
Background: The frontal sinus is often considered as the most challenging area to approach in Functional Endoscopic Sinus Surgery (FESS). Considerable variations in the shape, capacity and symmetry of frontal sinus have been reported.
\end{abstract}

Aim of Study: To provide better understanding of frontal sinus morphometry and anatomical variations of specific frontal recess cells and their prevalence among adult Egyptians.

Material and Methods: Coronal and sagittal CT scans of sixty adult persons of the Egyptian population (30 males and 30 females, assigned into Group 1; from 20 to 30 years, group 2 ; from 31 to 50 years and group 3; more than 50 years) were done to demonstrate the anatomy of the frontal sinus.

Results: A statistically significant difference in the width of the right sinus between group 2 and group 3 was revealed. Eighty percent of frontal sinuses were asymmetrical. Agger nasi cell was the most common encountered frontal recess cell and mostly bilateraly presented. The second common was Interfrontal sinus septal cell (IFSC). Statistically significant association was found between Fronta Bullar Cell (FBC) and frontal cell type 4 (FC4) but no statistically significant difference was found between males and females except for frontal cell type 3 (FC3) which was higher among females than males. Statistically significant positive correlation between A-P length of left FR and AP length of right FR was revealed, while no significant correlation was found between AP length and volume of ANC.

Conclusion: Awareness of frontal sinus dimensions frontal recess cells variations among Egyptians should be taken in consideration in safe frontal endoscopic surgery.

Key Words: Frontal-Sinus-Recess-Cells-Egyptians.

\section{Introduction}

OVER the last decade there has been increasing interest in the anatomy and surgical approaches to the frontal sinus. The frontal sinus is often consid-

Correspondence to: Dr. Reda A. Imam, E-Mail: abdelnasserreada@gmail.com ered as the most challenging area to approach in Functional Endoscopic Sinus Surgery (FESS). The frontal recess is the space into which the frontal sinus drains. This space is usually occupied by a number of air cells that affect the direction and position of this drainage pathway [1]. Serious complications in frontal sinus endoscopy are possible due to the frontal recess proximity to the anterior ethmoid artery, orbit, and anterior cranial fossa [2]. Considerable variations in the shape, capacity and symmetry of frontal sinus have been reported. It is the one that is of most interest and significance in forensic identification because of the individual characteristics which make the frontal sinus unique for every individual [3,4]. This study aims to provide better understanding of frontal sinus morphometry and anatomical variations of specific frontal recess cells and their prevalence among adult Egyptians. Aware knowledge of these dimensions and variations will help greatly in avoiding complications of frontal sinus surgery and recurrence of frontal sinus disease. It may affect the opinions of researches working on forensic personal identification using frontal sinus measurements.

\section{Material and Methods}

\section{CT scan study:}

A retrospective review of coronal and sagittal CT scans of sixty adult persons of the Egyptian population (30 males and 30 females) was performed in this study. The scans were obtained from Radiology Department, Faculty of Medicine, Cairo University in the period from November 2017 to July 2018. Examined persons were referred for investigating the head via CT scans for different reasons other than frontal sinus disease. 
The sixty examined persons were arranged in three age groups, each group includes 20 persons (10 males and 10 females) as follows: Group 1 (age from 20 to 30 years), group 2 (age from 31 to 50 years) and group 3 (age more than 50 years).

Inclusion criteria: Persons over 20 years whose CT scan clearly demonstrate the anatomy of the frontal sinus have been included in the study, as development of the frontal sinus is completed by approximately 20 years of age [5]

Exclusion criteria: Maxillofacial deformity or fractures, previous sinus surgery, sinonasal malignancy or evidence of sinusitis (opacification, airfluid level, and/or mucosal thickness greater than $3 \mathrm{~mm}$ in the frontal sinus) [6]

\section{2- Methods:}

\section{CT scan study:}

Studied CT scans were performed using Philips Medical Systems CT scanner. Patients were positioned in the prone position with the head extended and the gantry was perpendicular to the hard palate. Thin slices were performed from sphenoid sinuses posteriorly to the anterior wall of frontal sinus anteriorly Fig. (1). Scanning parameters included $3 \mathrm{~mm}$ slice thickness to avoid loss of any tissue detail, 2 seconds scanning time, $120 \mathrm{kVp}$ and 150 $\mathrm{mAs}$. In all cases, direct coronal and sagittal images were taken. The field of view was confined to the sinonasal area for optimal visualization. Bone and soft tissues were best visualized by filming on a window width of 1500-2000HU and window level of 200-300HU.

Measurements of frontal sinus that were used in this study include width, height and depth of the sinus on both sides. The lines that border the area of the frontal sinus were determined. The separation between the left and the right sides was based on the intersinus septum [7]. The greatest height, width and depth of each side were calculated from the maximum distance between the base and upper lines of the frontal sinus, the maximum distance between the medial and lateral lines of the right and left side and from the maximum distance between anterior and posterior lines respectively. Both height and width of the sinus were measured on coronal plane while the depth of the sinus was measured on sagittal plane Fig. (1).
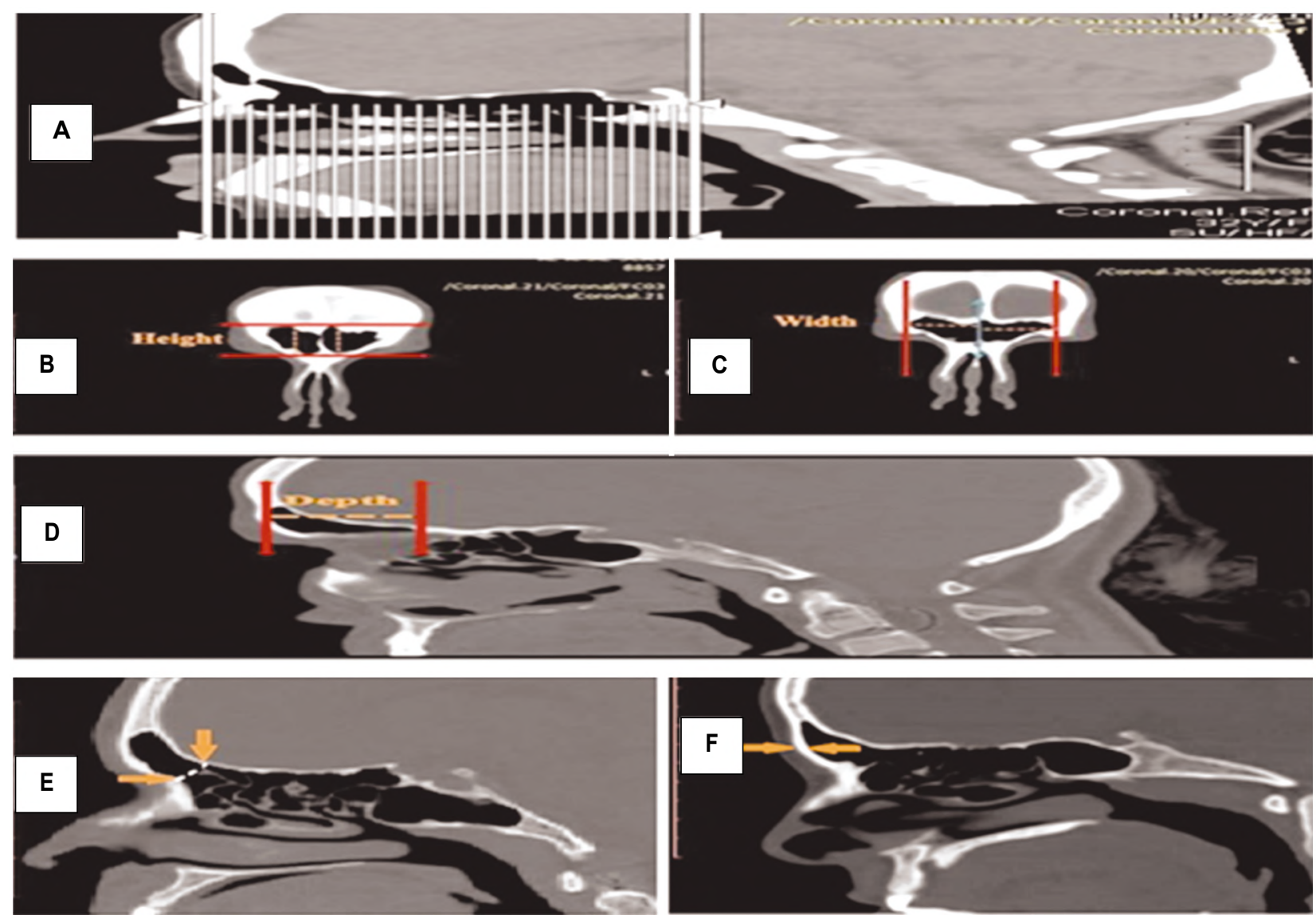

Fig. (1): Sagittal CT scans showing, A: The position of the patient and examined area. B, C \& D: Dimensions of frontal sinus. E: A-P length of frontal recess (dotted line) between frontal beak and superior attachment of ethmoid bulla (arrows). F: Thickness of anterior table of frontal sinus (arrows). 
Volume of right and left sinuses for each patient was calculated as (height X width X depth (according to the sinus volume, the Asymmetric Index (AI) was calculated to define whether the frontal sinuses for each patient were symmetrical or not. The formula of the asymmetric index was V $1 / \mathrm{V} 2$ $\mathrm{X} 100$, where V 1 was the volume of the smaller sinus and V2 was the volume of the larger sinus. According to the degree of symmetry, they were classified as symmetrical (AI=80-100) and asymmetrical $(\mathrm{AI}<80)$ [8].

Measurement of the anteroposterior length (A$P$ length) of frontal recess on both sides was obtained on sagittal plane and correlated with the volume of agger nasi cell. The A-P length of the frontal recess was defined as the length between the most prominent portion of the Frontal Beak (FB) and the superior attachment of the ethmoidal bullar lamella Fig. (1), while the volume of the ANC was defined as (the longest A-P diameter in the sagittal plane) $\mathrm{X}$ (the longest vertical diameter in the coronal plane) $\mathrm{X}$ (the longest diameter from side to side in the coronal plane) [9]. Measurement of the thickness of anterior table of frontal sinus on both sides was obtained on the sagittal images at the level of the orbital roof, $1 \mathrm{~cm}$ lateral to the midline Fig. (1) [10]. All linear measurements were obtained from each radiograph on RadiAnt viewer and were expressed in millimeters $(\mathrm{mm})$.

All CT scans were carefully interpreted for the presence of the following variations [11]:

- Frontal Bullar Cell (FBC).

- Suprabullar Cell (SBC).

- Supraorbital Ethmoid Cell (SOEC).

- Interfrontal Sinus Septal Cell (IFSC).

- Agger Nasi Cell (ANC).

- Frontal Cell type 1 (FC 1).

- Frontal Cell type 2 (FC 2).

- Frontal Cell type 3 (FC 3).

- Frontal Cell type 4 (FC 4).

\section{Statistical study:}

1- Measurements of frontal sinus were statistically analyzed for differences between right and left sides, sex and age groups differences.

2- Measurements of A-P length of frontal recess were statistically analyzed for differences between right and left sides, sex and age groups differences as well as their relation with the volume of ANC if present.

3- Measurements of the thickness of anterior table of frontal sinus were statistically analyzed for differences between right and left sides, sex and age groups differences.

4- Variations encountered were statistically analyzed for:

- Prevalence of each individual variation.

- Bilaterality of the variation.

- Sex differences.

- The inter-relationship between different anatomical variations of the frontal sinus.

Data was coded using Microsoft Office Excel 2016. Statistical analysis was done using IBM SPSS version 25. Frequencies (number) and relative frequencies (percent) were used to summarize qualitative variables while mean and standard deviations were used for quantitative variables. Comparison between groups was done using chisquare test, independent sample $t$-test and One Way ANOVA test. Pearson correlation was used to test for possible correlations between quantitative variables. $p$-alue less than or equal to 0.05 was considered significant.

\section{Results}

The study was conducted on 60 CT scans of 30 males and 30 females. Cases were arranged in 3 age groups as follows: Group 1: From 20 to 30, group 2: From 31 to 50 and group 3: More than 50 years, with 10 males and 10 females in each group.

Mean and standard deviation "SD" of all measurements of width, height and depth of frontal sinus as well as sinus volume, A-P length of frontal recess and thickness of anterior table of frontal sinus on each side were calculated and tabulated (Table 1).

Independent sample $t$-test was applied to compare differences in means between right and left sides and between males and females. Side-wise there was no statistically significant difference between right and left parameters ( $p$-value was more than 0.05) though all the measurements were slightly higher on the left than the right side except for the sinus volume which was higher on the right side (Table 1), Fig. (2). Gender-wise, statistically significant higher height, depth and volume of left frontal sinus were found among males than females ( $p$-value was less than 0.05 ) while no statistically significant difference in other parameters was found ( $p$-value was more than 0.05) although measurements were higher among males than females except for right A-P length of FR which was higher among females (Table 2), Fig. (2). 
Table (1): Differences of measurements between right and left frontal sinus (number $=60$ for each side).

\begin{tabular}{|c|c|c|c|c|c|}
\hline $\begin{array}{l}\text { Side } \\
\text { Parameter } \\
\end{array}$ & Minimum & Maximum & Mean & SD & $\begin{array}{c}p- \\
\text { value }\end{array}$ \\
\hline \multicolumn{6}{|l|}{ Width in mm: } \\
\hline Right & 5.50 & 45.70 & 23.40 & 8.45 & 0.665 \\
\hline Left & 11.50 & 44.30 & 24.04 & 7.63 & \\
\hline \multicolumn{6}{|l|}{ Height in $\mathrm{mm}$ : } \\
\hline Right & 5.22 & 44.70 & 19.74 & 8.59 & 0.915 \\
\hline Left & 6.60 & 48.50 & 19.91 & 9.04 & \\
\hline \multicolumn{6}{|l|}{ Depth in mm: } \\
\hline Right & 5.20 & 45.80 & 18.84 & 8.62 & 0.388 \\
\hline Left & 6 & 38.90 & 20.13 & 7.69 & \\
\hline \multicolumn{6}{|l|}{ Volume in $\mathrm{mm}^{3}$ : } \\
\hline Right & 257.40 & 70643.52 & 11288.97 & 13461.54 & 0.961 \\
\hline Left & 1014.90 & 60184.13 & 11179.52 & 10720.86 & \\
\hline \multicolumn{6}{|l|}{$A-P$ length of } \\
\hline Right & 4.20 & 17.40 & 9.39 & 3.08 & 0.170 \\
\hline Left & 4.74 & 17.90 & 10.16 & 2.971 & \\
\hline \multicolumn{6}{|l|}{$\begin{array}{l}\text { Anterior table } \\
\text { thickness in mm: }\end{array}$} \\
\hline Right & 1.40 & 5.50 & 3.27 & 0.97 & 0.264 \\
\hline Left & 2.00 & 6.70 & 3.48 & 1.10 & \\
\hline
\end{tabular}

A-P : Anteroposterior.

FR : Frontal Recess.

SD : Standard Deviation.

Table (2): Differences of measurements of right and left frontal sinus between males and females (number $=30$ for each gender).

\begin{tabular}{|c|c|c|c|c|}
\hline Parameter & Gender & Mean & SD & $p$-value \\
\hline - Rt. width in mm & $\begin{array}{l}\text { Male } \\
\text { Female }\end{array}$ & $\begin{array}{l}23.93 \\
22.88\end{array}$ & $\begin{array}{l}9.59 \\
7.26\end{array}$ & 0.636 \\
\hline - Lt. width in mm & $\begin{array}{l}\text { Male } \\
\text { Female }\end{array}$ & $\begin{array}{l}24.38 \\
23.71\end{array}$ & $\begin{array}{l}7.89 \\
7.49\end{array}$ & 0.735 \\
\hline - Rt. height in $\mathrm{mm}$ & $\begin{array}{l}\text { Male } \\
\text { Female }\end{array}$ & $\begin{array}{l}21.06 \\
18.42\end{array}$ & $\begin{array}{l}9.36 \\
7.67\end{array}$ & 0.238 \\
\hline - Lt. height in $\mathrm{mm}$ & $\begin{array}{l}\text { Male } \\
\text { Female }\end{array}$ & $\begin{array}{l}22.30 \\
17.53\end{array}$ & $\begin{array}{l}9.33 \\
8.20\end{array}$ & $0.040 *$ \\
\hline - Rt. depth in mm & $\begin{array}{l}\text { Male } \\
\text { Female }\end{array}$ & $\begin{array}{l}20.01 \\
17.66\end{array}$ & $\begin{array}{l}9.45 \\
7.69\end{array}$ & 0.297 \\
\hline - Lt. depth in mm & $\begin{array}{l}\text { Male } \\
\text { Female }\end{array}$ & $\begin{array}{l}22.24 \\
18.02\end{array}$ & $\begin{array}{l}8.13 \\
6.72\end{array}$ & $0.032 *$ \\
\hline - Rt. volume in $\mathrm{mm}^{3}$ & $\begin{array}{l}\text { Male } \\
\text { Female }\end{array}$ & $\begin{array}{l}14251.27 \\
8326.67\end{array}$ & $\begin{array}{l}17515.42 \\
6612.81\end{array}$ & 0.088 \\
\hline - Lt. volume in $\mathrm{mm}^{3}$ & $\begin{array}{l}\text { Male } \\
\text { Female }\end{array}$ & $\begin{array}{l}14395.44 \\
7963.60\end{array}$ & $\begin{array}{l}13311.90 \\
5935.74\end{array}$ & $0.019 *$ \\
\hline $\begin{array}{l}\text { - A-P length of Rt. FR } \\
\text { in } \mathrm{mm}\end{array}$ & $\begin{array}{l}\text { Male } \\
\text { Female }\end{array}$ & $\begin{array}{l}9.10 \\
9.69\end{array}$ & $\begin{array}{l}3.007 \\
3.17\end{array}$ & 0.457 \\
\hline $\begin{array}{l}\text { - A-P length of Lt. FR } \\
\text { in } \mathrm{mm}\end{array}$ & $\begin{array}{l}\text { Male } \\
\text { Female }\end{array}$ & $\begin{array}{l}10.22 \\
10.10\end{array}$ & $\begin{array}{l}3.14 \\
2.83\end{array}$ & 0.872 \\
\hline $\begin{array}{l}\text { - Rt. anterior table } \\
\text { thickness in mm }\end{array}$ & $\begin{array}{l}\text { Male } \\
\text { Female }\end{array}$ & $\begin{array}{l}3.50 \\
3.04\end{array}$ & $\begin{array}{l}1.09 \\
0.77\end{array}$ & 0.066 \\
\hline $\begin{array}{l}\text { - Lt. anterior table } \\
\text { thickness in mm }\end{array}$ & $\begin{array}{l}\text { Male } \\
\text { Female }\end{array}$ & $\begin{array}{l}3.70 \\
3.27\end{array}$ & $\begin{array}{l}1.27 \\
0.87\end{array}$ & 0.139 \\
\hline
\end{tabular}
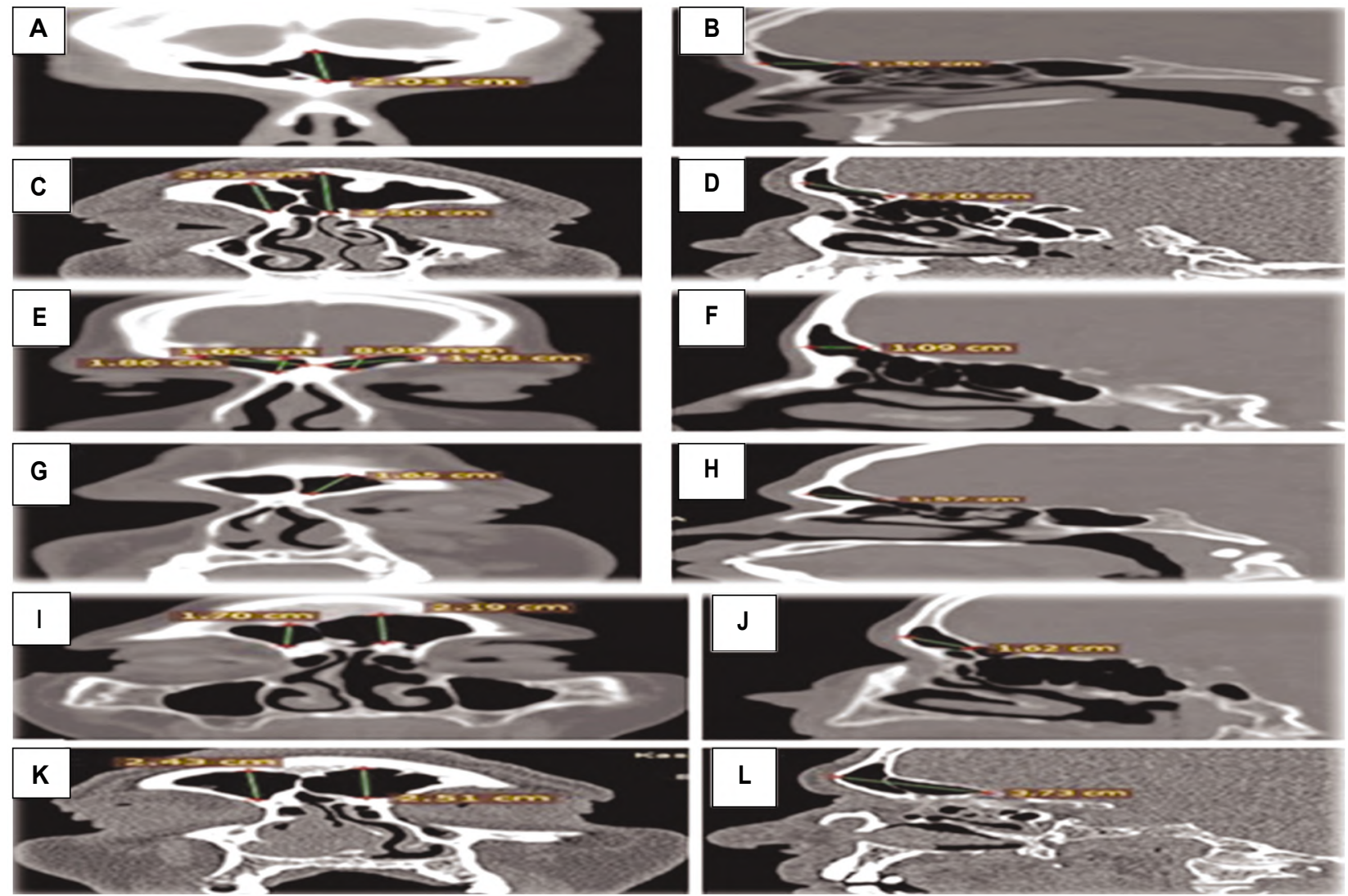

Fig. (2): Coronal and sagittal CT scans showing the difference in left height and left depth of frontal sinus between male and female in groups 1, $2 \& 3$. Group 1 coronal (A) and sagittal (B) CT scans of 23 years old female, and coronal (C) and sagittal (D) CT scans of 20 years old male. Group 2 coronal (E) and sagittal (F) CT scans of 31 years old female, and coronal $(\mathrm{G})$ and sagittal $(\mathrm{H})$ CT scans of 35 years old male. Group 3 coronal (I) and sagittal (J) CT scans of 68 years old female, and coronal (K) and sagittal (L) CT scans of 68 years old male. 
When the independent sample $t$-test was applied to compare parameters of all sinuses between males and females regardless of the side, statistically significant higher height, depth and volume of frontal sinus as well as anterior table thickness was found among males ( $p$-value was less than 0.05) (Table 3).

The A-P length of FR was slightly higher on the left than the right side (Table 1) and higher among females than males (Table 3 ) but this wasn't statistically significant.

Regarding thickness of the anterior table of frontal sinus, it was slightly higher on the left than the right side and higher among males than females with statistically significant difference $(p=0.019)$ (Tables 1,3).

Table (3): Differences of measurements of all frontal sinuses between males and females (number $=60$ for each gender).

\begin{tabular}{|c|c|c|c|c|}
\hline Parameter & Gender & Mean & SD & $p$-value \\
\hline \multirow[t]{2}{*}{ - Width in mm } & Male & 24.15 & 8.71 & 0.559 \\
\hline & Female & 23.29 & 7.33 & \\
\hline \multirow[t]{2}{*}{ - Height in mm } & Male & 21.68 & 9.29 & $0.020 *$ \\
\hline & Female & 17.98 & 7.89 & \\
\hline \multirow[t]{2}{*}{ - Depth in mm } & Male & 21.13 & 8.81 & $0.027 *$ \\
\hline & Female & 17.84 & 7.16 & \\
\hline \multirow[t]{2}{*}{ - Volume in $\mathrm{mm}^{3}$} & Male & 14323.35 & 15424.07 & $0.005 *$ \\
\hline & Female & 8145.14 & 6232.61 & \\
\hline \multirow{2}{*}{$\begin{array}{l}\text { - A-P length of FR in } \\
\text { mm }\end{array}$} & Male & 9.66 & 3.10 & 0.671 \\
\hline & Female & 9.89 & 2.99 & \\
\hline \multirow{2}{*}{$\begin{array}{l}\text { - Anterior table } \\
\text { thickness in mm }\end{array}$} & Male & 3.60 & 1.18 & $0.019 *$ \\
\hline & Female & 3.16 & 0.82 & \\
\hline
\end{tabular}

The 3 age groups' means of measurements were compared using one way analysis of variance test (one way ANOVA test). The only statistically significant difference between age groups was found in width of the right sinus $(p=0.027)$. By post hoc test the difference was found between group 2 and group 3 (Table 4). By comparing measurements between the 3 age groups; width, height, depth and volume of the right sinus reached their peak in group 2, and were nearly equal on the left side in groups 2 and 3 except for the left depth which was higher in group 3 than group 1 and 2 . However, group 1 showed the highest values of left height, left width and left sinus volume (Tables 4, 5). No statistically significant difference was found between age groups when all parameters were compared regardless of the side.
Table (4): Differences of measurements of right frontal sinus between age groups (number $=20$ for each group).

\begin{tabular}{|c|c|c|c|c|}
\hline \multicolumn{2}{|l|}{ Parameter } & \multirow{2}{*}{$\frac{\text { Mean }}{23.77}$} & \multirow{2}{*}{$\frac{S D}{7.92}$} & \multirow{2}{*}{$\frac{p \text {-value }}{0.027 *}$} \\
\hline - Rt. width in mm: & Group 1 & & & \\
\hline & Group 2 & 26.75 & 8.08 & \\
\hline & Group 3 & 19.70 & 8.21 & \\
\hline \multirow[t]{3}{*}{ - Rt. height in mm: } & Group 1 & 18.59 & 7.91 & 0.253 \\
\hline & Group 2 & 22.35 & 10.08 & \\
\hline & Group 3 & 18.29 & 7.36 & \\
\hline \multirow[t]{3}{*}{ - Rt. depth in mm: } & Group 1 & 17.66 & 8.26 & 0.500 \\
\hline & Group 2 & 20.69 & 9.20 & \\
\hline & Group 3 & 18.16 & 8.52 & \\
\hline \multirow[t]{3}{*}{ - Volume in $\mathrm{mm}^{3}$ : } & Group 1 & 10331.57 & 15031.28 & 0.230 \\
\hline & Group 2 & 15339.02 & 15908.20 & \\
\hline & Group 3 & 8196.33 & 7443.47 & \\
\hline \multirow{3}{*}{$\begin{array}{l}\cdot \text { A-P length of Rt. FR in } \\
\quad m m:\end{array}$} & Group 1 & 9.69 & 2.33 & 0.871 \\
\hline & Group 2 & 9.26 & 3.45 & \\
\hline & Group 3 & 9.23 & 3.46 & \\
\hline \multirow{3}{*}{$\begin{array}{l}\text { - Rt. anterior table } \\
\text { thickness in mm: }\end{array}$} & Group 1 & 3.41 & 1.14 & 0.188 \\
\hline & Group 2 & 3.46 & 0.96 & \\
\hline & Group 3 & 2.95 & 0.72 & \\
\hline
\end{tabular}

Table (5): Differences of measurements of left frontal sinus between age groups (number=20 for each group).

\begin{tabular}{lllll}
\hline Parameter & & Mean & SD & $p$-value \\
\hline • Lt. width in mm: & Group 1 & 24.21 & 7.76 & 0.993 \\
& Group 2 & 23.95 & 8.90 & \\
& Group 3 & 23.98 & 6.44 & \\
• Lt. height in mm: & Group 1 & 20.25 & 10.12 & 0.935 \\
& Group 2 & 20.19 & 9.31 & \\
• Lt. depth in mm: & Group 3 & 19.30 & 8.002 & \\
& Group 1 & 18.63 & 8.88 & 0.411 \\
& Group 2 & 19.88 & 7.41 & \\
• Volume in mm ${ }^{3}:$ & Group 3 & 21.88 & 6.67 & \\
& Group 1 & 11904.65 & 13995.10 & 0.929 \\
& Group 2 & 11030.87 & 10610.82 & \\
• A-P length of Lt. & Group 3 & 10603.03 & 6894.26 & \\
FR in mm: & Group 1 & 10.35 & 2.04 & 0.598 \\
thickness in mm: & Group 2 & 9.61 & 3.62 & \\
& Group 3 & 10.52 & 3.10 & \\
\hline & Group 2 & 3.72 & 1.21 & 0.447 \\
\hline
\end{tabular}

Comparing the A-P length of FR and anterior table thickness between age groups, the A-P length of FR showed a decline on the left side in group 2 while on the right side it was higher in group 1 and nearly equal in groups 2 and 3 (Tables 4,5), Figs. $(3,4,5)$. As regards anterior table thickness, a decline was observed in group 3 especially on the right side but $p$-value was more than 0.05 (statistically insignificant) (Tables 4,5), Figs. (3-5). 


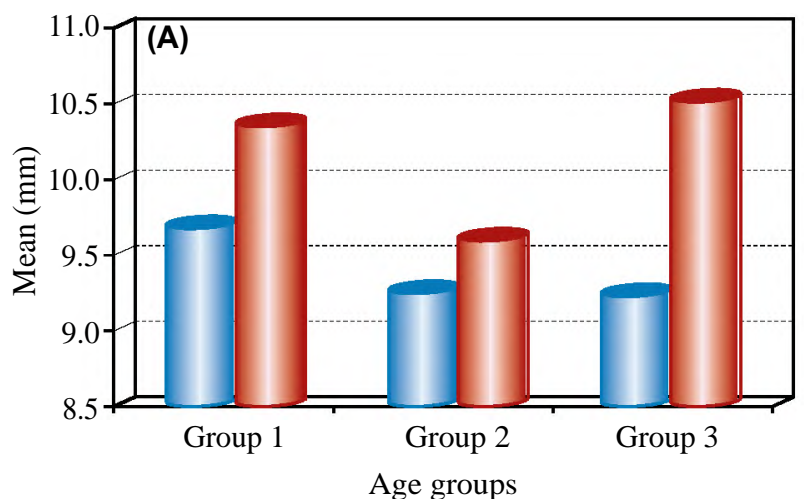

1 Rt. A-P length of FR
Lt. A-P length of FR

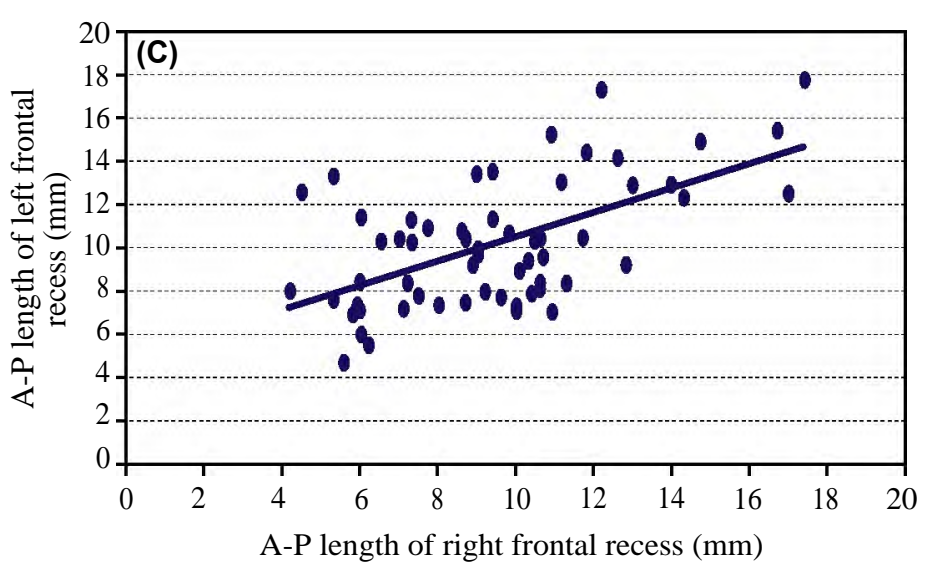

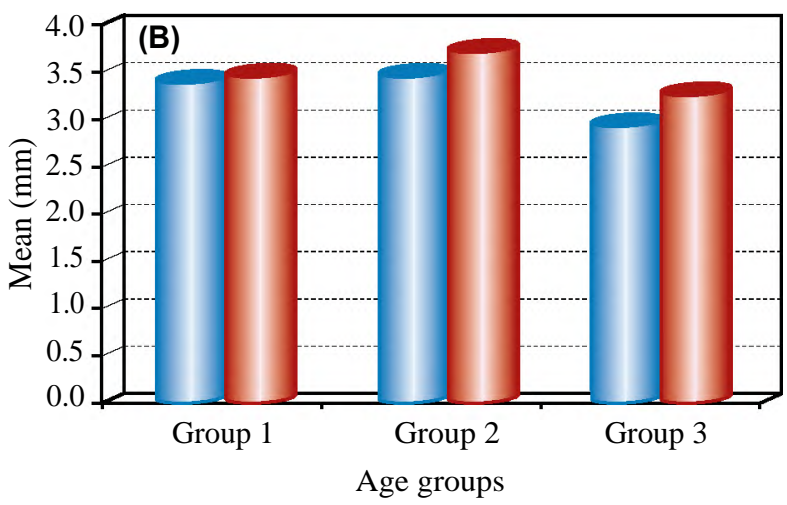

Rt. anterior table thickness

Lt. anterior table thickness

Fig. (3): A \& B bar charts showing differences of means of right and left A-P length of frontal recess between age groups (bar chart A), differences of means of right and left anterior table thickness of frontal sinus between age groups (bar chart B). C: Correlation between A-P length of right and left frontal recesses $(r=0.611, p=0.001)$.
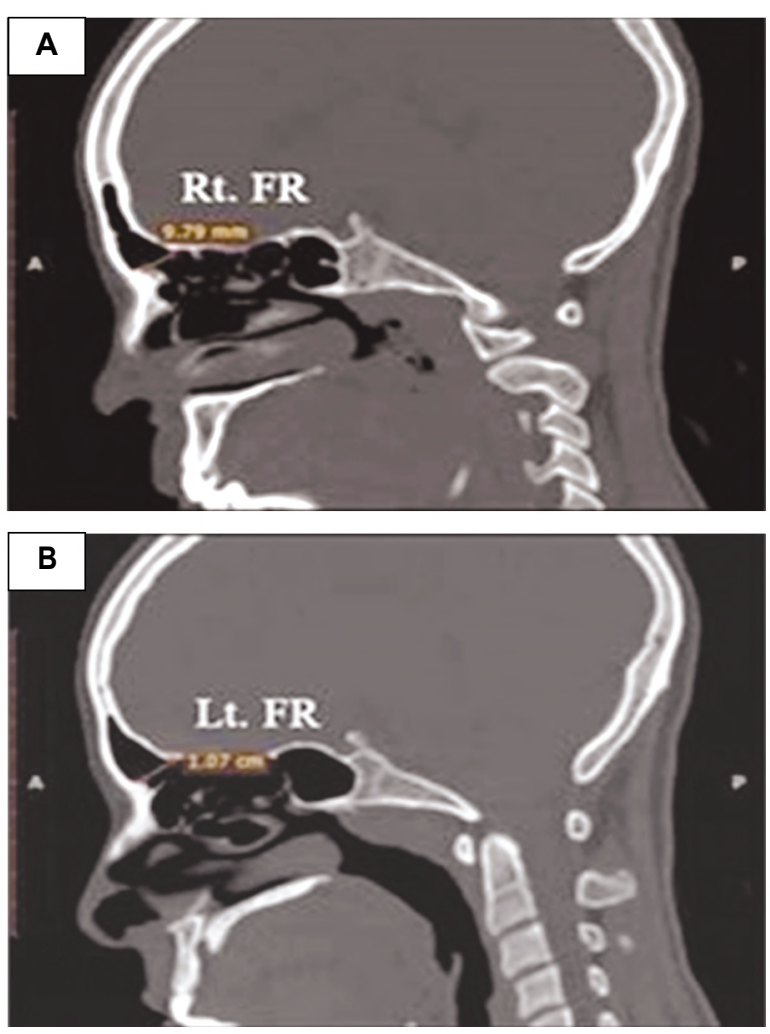
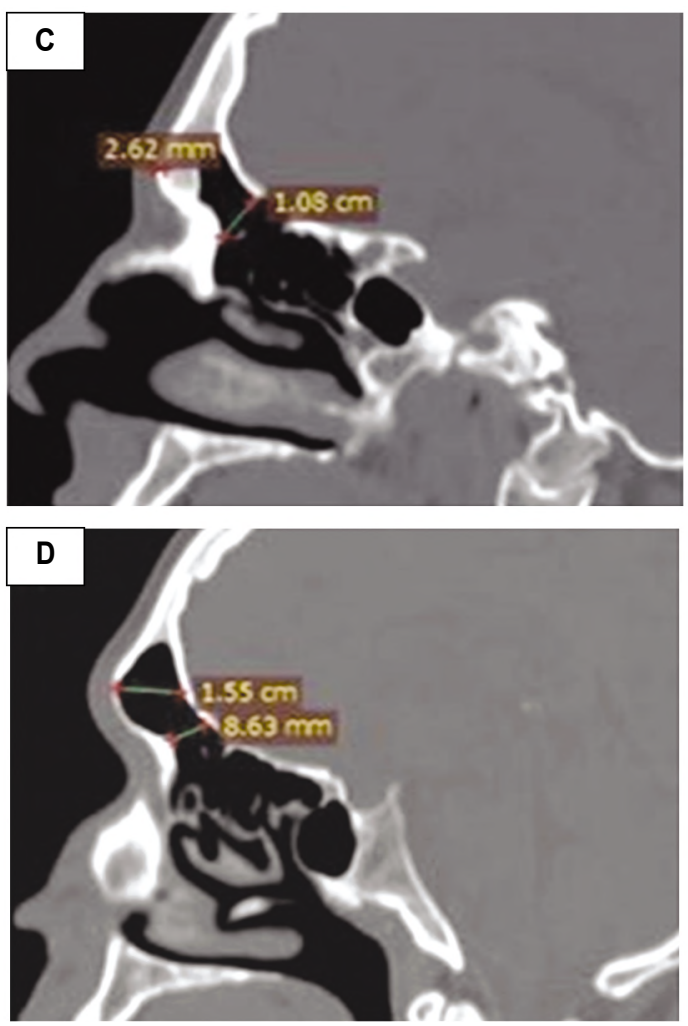

Fig. (4): Sagittal (A and B) CT scans of 23 years old female, and sagittal (C and D) CT scans of 28 years old male showing the correlation between right and left A-P length of FR in group 1 . 


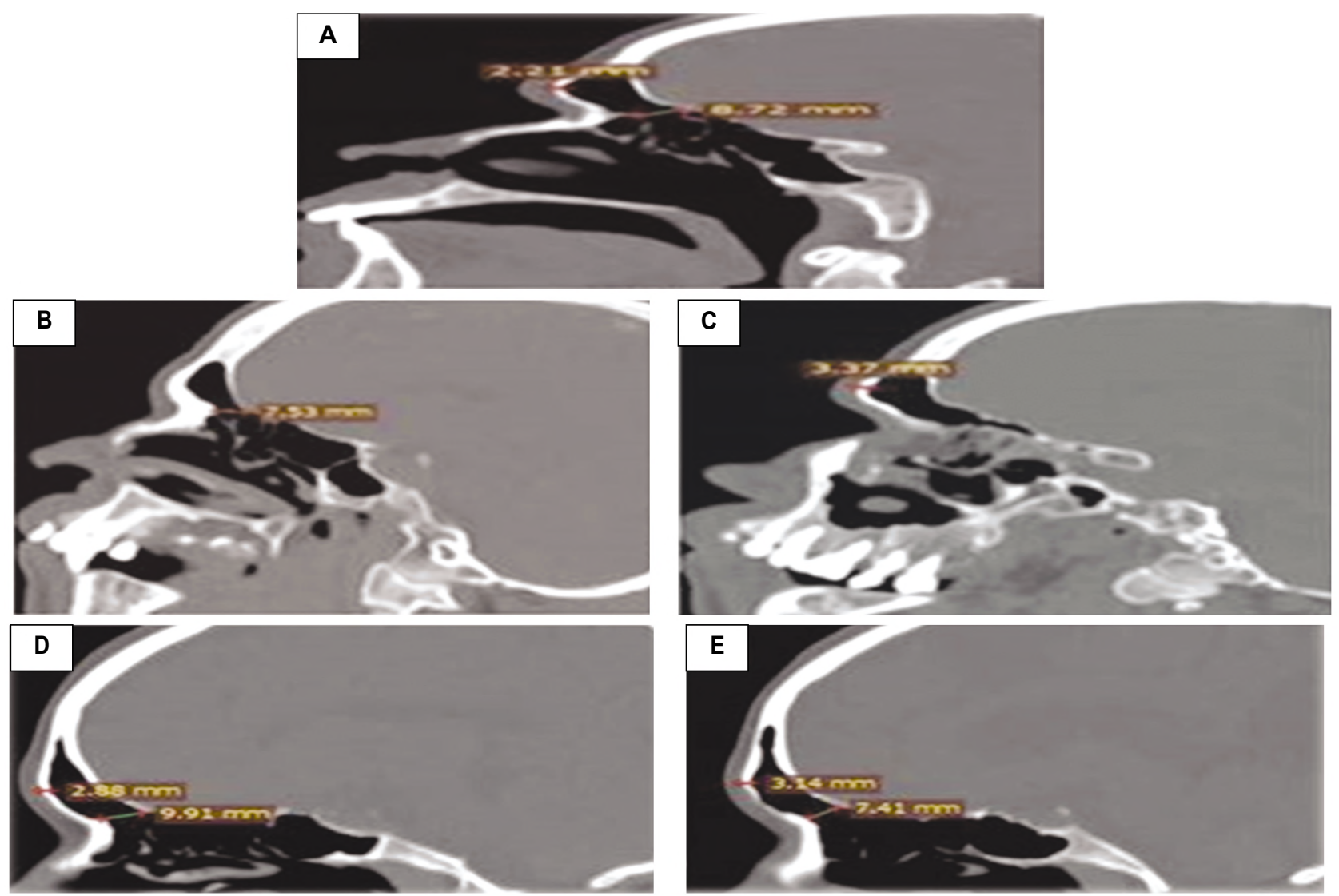

Fig. (5): Sagittal (A, B and C) CT scans of 40 years old male, and sagittal (D and E) CT scans of 45 years old female showing the correlation between right and left A-P length of FR and difference in anterior table thickness between male and female in group 2.
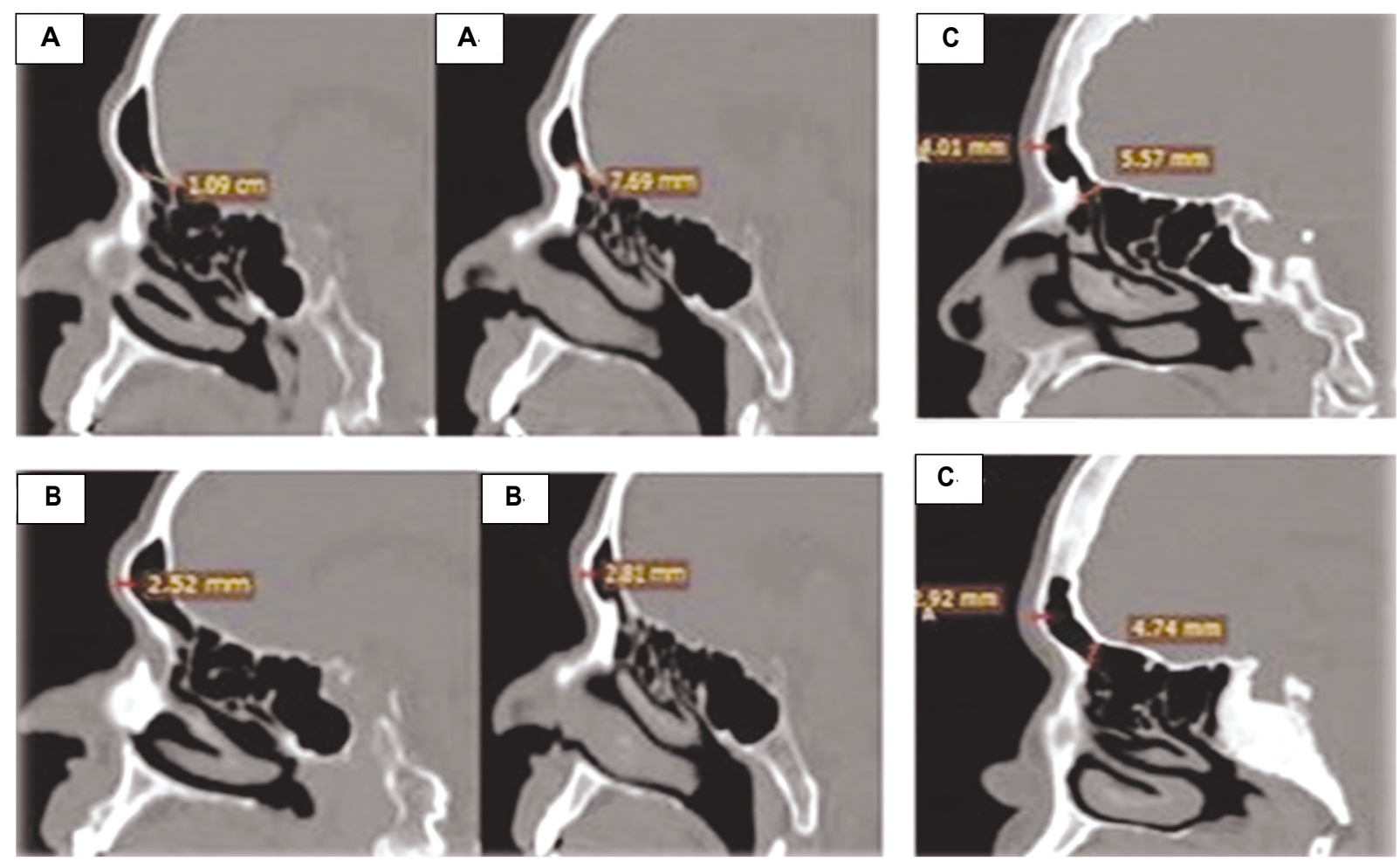

Fig. (6): Sagittal (A, A', B and B') CT scans of 62 years old male, and sagittal (C and C') CT scans of 50 years old female showing the correlation between right and left A-P length of FR and difference in anterior table thickness between male and female in group 3. 
Correlation between right and left A-P length of FR and between volume of ANC and A-P length of FR was analyzed using Pearson correlation. Correlation coefficient " $r$ " was significant at the 0.01 level (2-tailed). Statistically significant positive correlation was found between A-P length of left FR and AP length of right FR ( $p$-value $>r$; $r=0.611, p$-value $<0.001$ ) (Table 6) but no correlation was found between AP length and volume of ANC (Table 6).

Frontal sinus showed great asymmetry between right and left sides, deviation of interfrontal septum from midline was common as well as intrasinus septations Fig. (7). By applying the formula of the asymmetric index, $48(80 \%)$ out of the 60 studied population were asymmetrical and $12(20 \%)$ were symmetrical (Table 7).

Agger nasi cell was found in 97 out of the 120 studied sides; 84 were bilaterally present and 13 were only unilateral (Tables 8,9), Fig. (8). Volume of ANC was generally higher on the right side than the left side (Table 10) but this wasn't statistically significant.
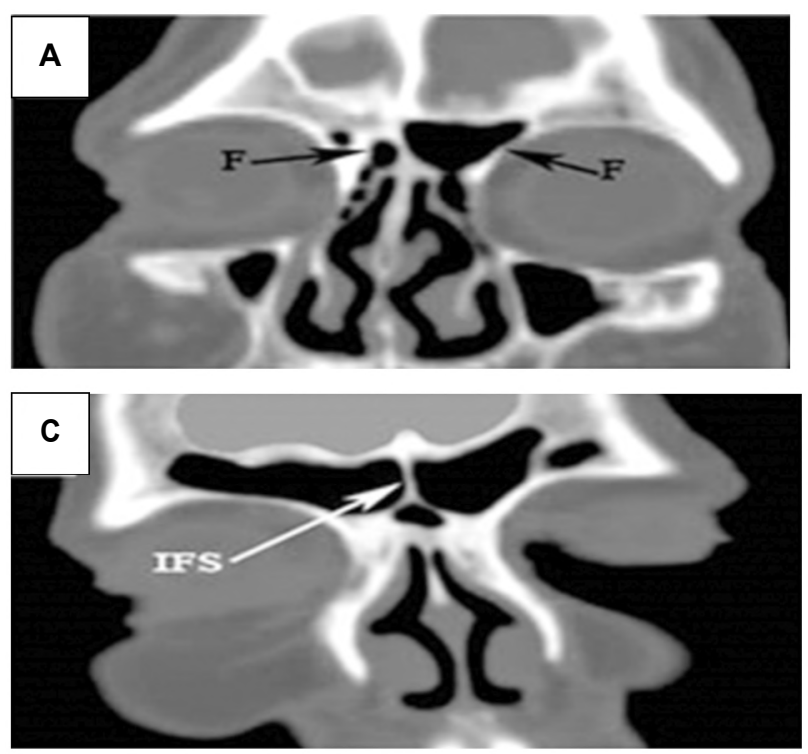

Table (6): Pearson correlation between A-P length of right and left FR and volume of right and left ANC.

\begin{tabular}{|c|c|c|c|c|}
\hline & & $\begin{array}{l}\text { A-P length } \\
\text { of Lt. FR }\end{array}$ & $\begin{array}{l}\text { Volume of } \\
\text { Rt. ANC }\end{array}$ & $\begin{array}{l}\text { Volume of } \\
\text { Lt. ANC }\end{array}$ \\
\hline \multirow[t]{3}{*}{ A-P length of Rt. FR: } & & $0.611 * *$ & -0.034 & \\
\hline & $p$-value & $<0.001$ & 0.806 & \\
\hline & $\mathrm{N}$ & 55 & 55 & \\
\hline \multirow[t]{3}{*}{ A-P length of Lt. FR: } & & & & -0.213 \\
\hline & $p$-value & & & 0.119 \\
\hline & $\mathrm{N}$ & & & 55 \\
\hline \multirow[t]{3}{*}{ Volume of Lt. ANC: } & $r$ & & -0.144 & \\
\hline & $p$-value & & 0.294 & \\
\hline & $\mathrm{N}$ & & 55 & \\
\hline
\end{tabular}

Table (7): Descriptive analysis of frontal sinus symmetry.

\begin{tabular}{lcc}
\hline & Frequency & Percent \\
\hline Asymmetrical & 48 & 80.0 \\
Symmetrical & 12 & 20.0 \\
\hline Total & 60 & 100.0 \\
\hline
\end{tabular}
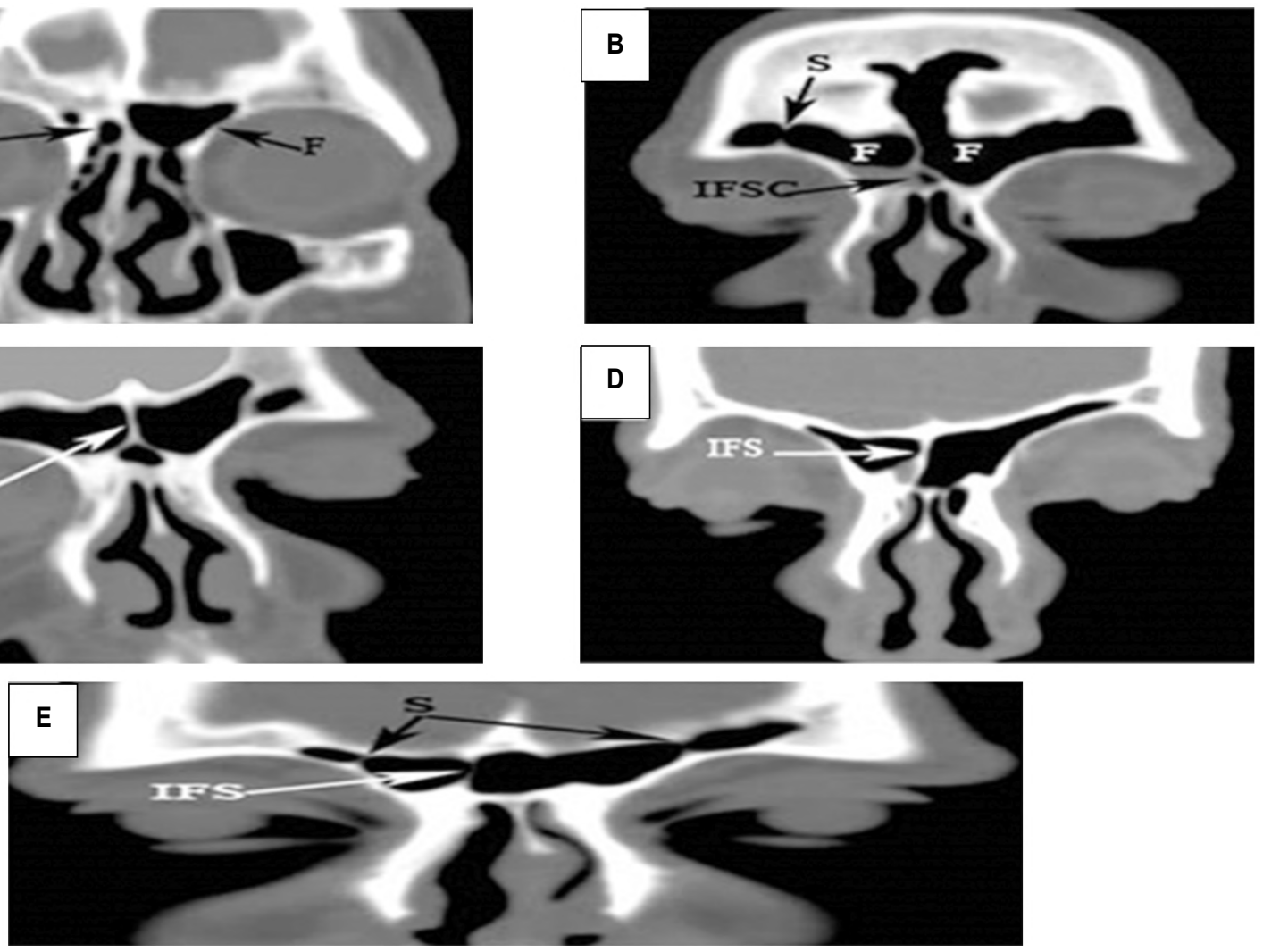

Fig. (7): Coronal CT scans of A- 62 years old male (group 3) showing asymmetrical right and left frontal sinuses (F) with the right sinus is poorly developed. B- 51 years old female (group 3) showing asymmetrical right and left frontal sinuses (F) with the left sinus pneumatizes widely upwards in the frontal bone. Interfrontal Septal Cell (IFSC) and right intrasinus septation (S) are also seen. C- 60 years old female (group 3) showing midline Interfrontal Septum (IFS). D- 23 years old female (group 1) showing deviation of the interfrontal septum to the right. E- 27 years old male (group 1) showing deviation of the interfrontal septum to the right and bilateral intrasinus septations. 
Table (8): Descriptive analysis of agger nasi cell.

\begin{tabular}{lcc}
\hline ANC & Frequency & Percent \\
\hline Unilateral & 13 & 10.8 \\
Bilateral & 84 & 70.0 \\
Absent & 23 & 19.2 \\
\hline Total & 120 & 100.0 \\
\hline
\end{tabular}

Table (9): Percentage and cumulative percentage of unilateral and bilateral ANC.

\begin{tabular}{lcccc}
\hline ANC & \multicolumn{1}{c}{ Frequency } & Percent & Valid percent & Cumulative percent \\
\hline Unilateral & 13 & 13.4 & 13.4 & 13.4 \\
Bilateral & 84 & 86.6 & 86.6 & 86.6 \\
\hline Total & 97 & 100.0 & 100.0 & 100.0 \\
\hline
\end{tabular}

Table (10): Volume of agger nasi cell on both sides.

\begin{tabular}{lcccccc}
\hline & Number & Minimum & Maximum & Mean & SD & $p$-value \\
\hline Rt. ANC volume in $\mathrm{mm}^{3}$ & 49 & 37.70 & 1190.20 & 292.60 & 222.16 & 0.298 \\
Lt. ANC volume in $\mathrm{mm}^{3}$ & 48 & 46.20 & 650.90 & 253.28 & 137.45 & \\
\hline
\end{tabular}
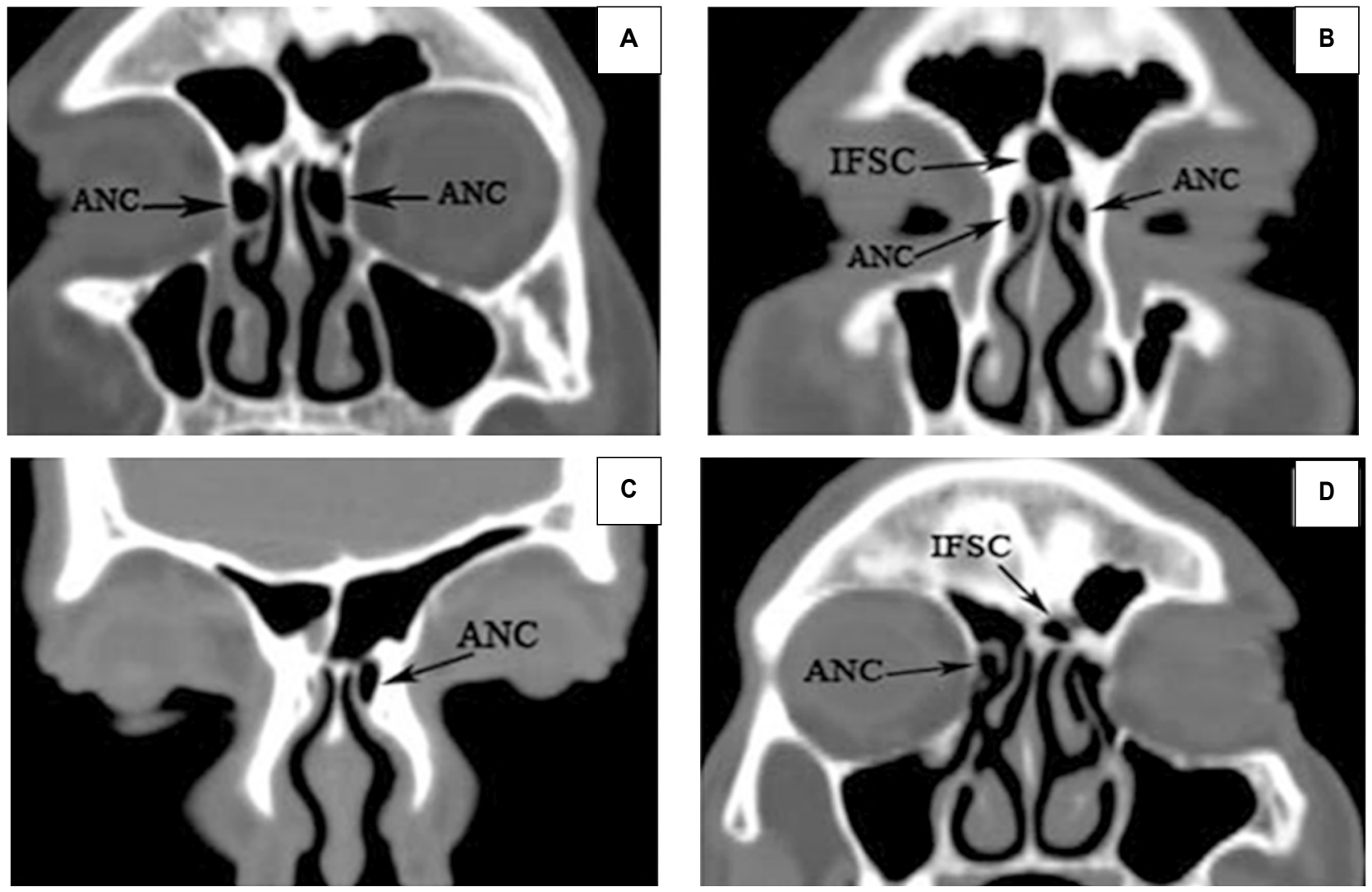

Fig. (8): Coronal CT scan of A- 28 years old male (group 1) showing bilateral agger nasi cell (ANC). B- 31 years old male (group 2) showing bilateral agger nasi cell associated with Interfrontal Septal Cell (IFSC). C- 23 years old female (group 1) showing left agger nasi cell. D- 52 years old male (group 3) showing right agger nasi cell associated with Interfrontal Septal Cell (IFSC).

Frequency and bilaterality of each cell type of frontal recess cells among the 120 studied sides are shown on (Tables 11,12,13) and Figs. $(9,10)$. Among the different types of frontal recess cells, IFSC Figs. $(9,10)$ was the most frequently encountered cell after agger nasi cell, followed by SOEC and FBC. FC2 and SBC were the second most frequent followed by FC1, FC3 and FC4 respectively. Differences in frontal recess cells between male and female, which were analyzed by Chi- square test, were not statistically significant ( $p$ value was more than 0.05) except in FC3 which was significantly higher among females $(p=0.05)$ (Table 14). Association between different types of frontal recess cells using Chi-square test showed only significant association between FC4 and FBC $(p=0.025)$ (Table 15), Figs. $(9,10)$. No other significant associations were noticed between other cells ( $p$-value was more than 0.05 ). 


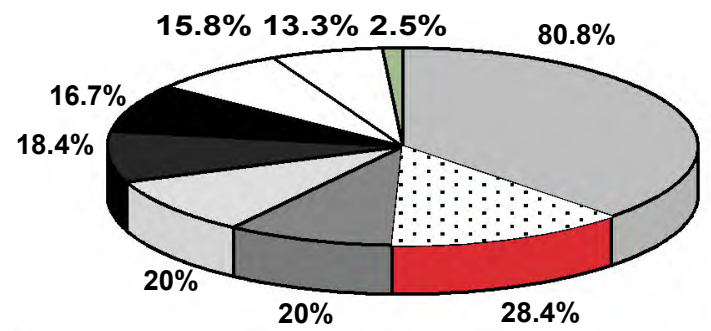

(A)
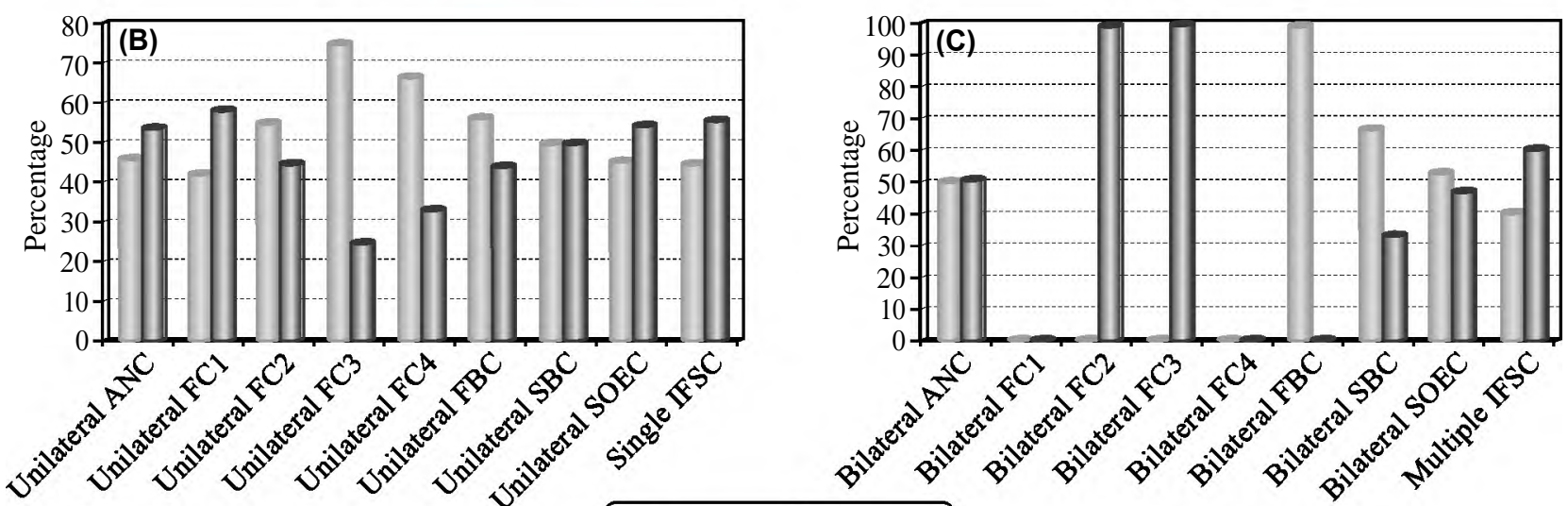

\section{Male $\square$ Female}

Fig. (9): A: Pie chart showing the frequencies of individual types of frontal recess cells in the 120 studied sides (60 CT scans $=120$ right and left sides). B: Bar chart showing difference of frequencies of unilateral frontal recess cells and single IFSC between male and female. $\mathrm{C}$ : Bar chart showing difference of frequencies of bilateral frontal recess cells and multiple IFSC between male and female.
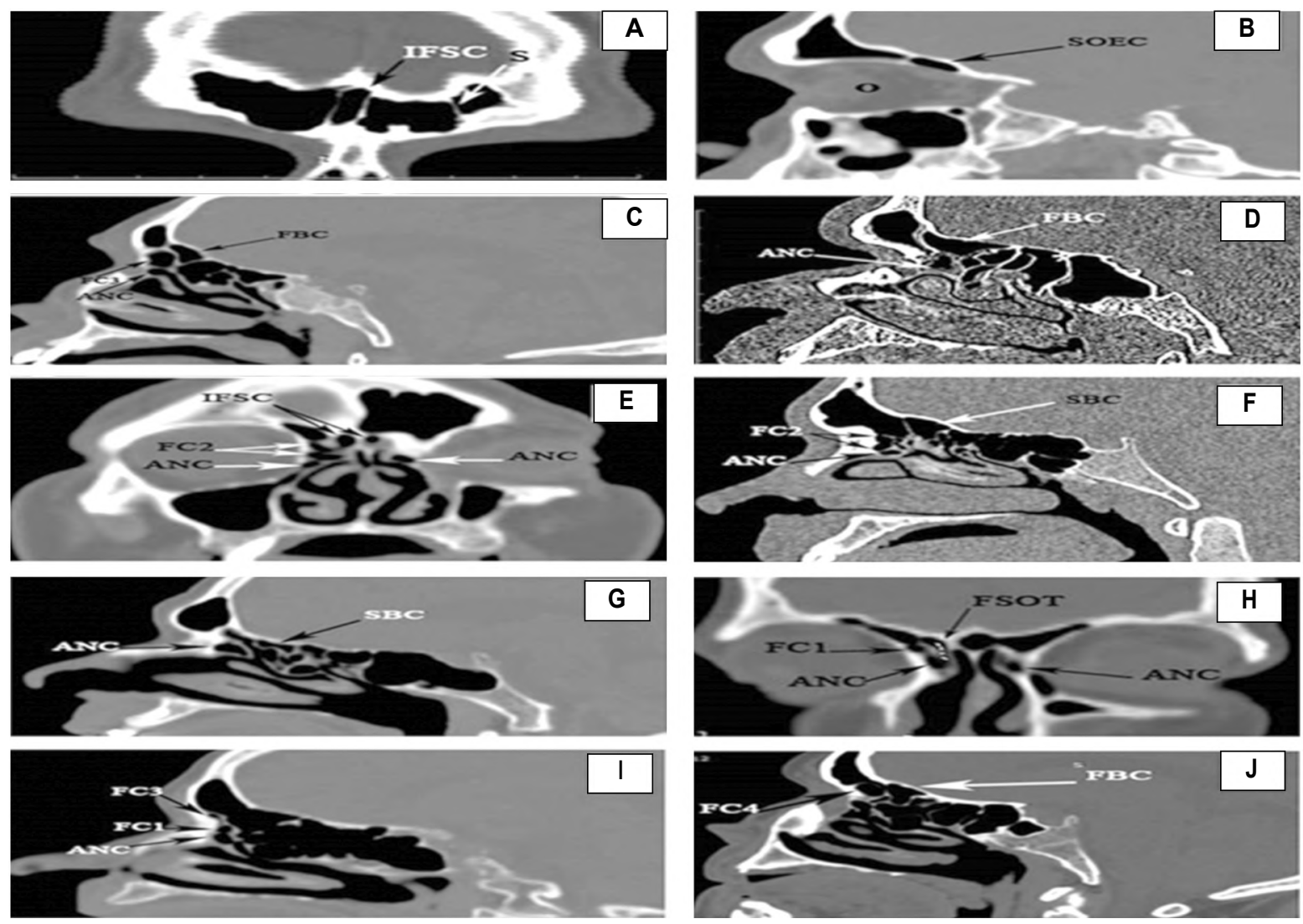

Fig. (10): Coronal and sagittal CT scan showing A- IFSC and left intrasinus septation (S). B- Single SOEC. C- FC3 above ANC and FBC. D- FBC and ANC. E- Right FC2 above ANC. Multiple IFSC are seen. F- FC2 above ANC. G- Suprabullar cell and ANC. H- Right FC1 above ANC and lateral to the right Frontal Sinus Outflow Tract (FSOT) (dotted line). I- FC1 and small FC3 "with its own drainage tract". J- FC4. (Age for A-J was 54, 37, 45, 47, 51, 21, 62, 57, 68, 45 years old respectively. Sex for A, B, C, E, F and G was male while D, H, I and J were female). 
Table (11): Descriptive analysis of FCs types 1:4.

\begin{tabular}{|c|c|c|}
\hline & Frequency & Percent \\
\hline \multicolumn{3}{|l|}{$F C 1:$} \\
\hline Unilateral & 19 & 15.8 \\
\hline Bilateral & 0 & 0 \\
\hline Absent & 101 & 84.2 \\
\hline Total & 120 & 100.0 \\
\hline \multicolumn{3}{|l|}{$F C 2:$} \\
\hline Unilateral & 20 & 16.7 \\
\hline Bilateral & 2 & 1.7 \\
\hline Absent & 98 & 81.6 \\
\hline Total & 120 & 100.0 \\
\hline \multicolumn{3}{|l|}{ FC3: } \\
\hline Unilateral & 8 & 6.6 \\
\hline Bilateral & 8 & 6.7 \\
\hline Absent & 104 & 86.7 \\
\hline Total & 120 & 100.0 \\
\hline \multicolumn{3}{|l|}{$F C 4:$} \\
\hline Unilateral & 3 & 2.5 \\
\hline Bilateral & 0 & 0 \\
\hline Absent & 117 & 97.5 \\
\hline Total & 120 & 100.0 \\
\hline
\end{tabular}

FC: Frontal Cell.

Table (12): Descriptive analysis of IFSC and SOEC.

\begin{tabular}{|c|c|c|}
\hline & Frequency & Percent \\
\hline \multicolumn{3}{|l|}{ IFSC: } \\
\hline Single & 29 & 24.2 \\
\hline Multiple & 5 & 4.2 \\
\hline Absent & 86 & 71.6 \\
\hline Total & 120 & 100.0 \\
\hline \multicolumn{3}{|l|}{ SOEC: } \\
\hline Unilateral & 16 & 13.3 \\
\hline Bilateral & 8 & 6.7 \\
\hline Absent & 96 & 80 \\
\hline Total & 120 & 100.0 \\
\hline \multicolumn{3}{|c|}{$\begin{array}{l}\text { IFSC : Interfrontal Septal Cell. } \\
\text { SOEC : Supraorbital Ethmoid Cell. }\end{array}$} \\
\hline \multicolumn{3}{|c|}{ Table (13): Descriptive analysis of FBC and SBC. } \\
\hline & Frequency & Percent \\
\hline \multicolumn{3}{|l|}{$F B C:$} \\
\hline Unilateral & 16 & 13.3 \\
\hline Bilateral & 8 & 6.7 \\
\hline Absent & 96 & 80 \\
\hline Total & 120 & 100.0 \\
\hline \multicolumn{3}{|l|}{$S B C:$} \\
\hline Unilateral & 14 & 11.7 \\
\hline Bilateral & 6 & 5.0 \\
\hline Absent & 100 & 83.3 \\
\hline Total & 120 & 100.0 \\
\hline
\end{tabular}

FBC : Frontal Bullar Cell.

SBC : Suprabullar Cell.
Table (14): Differences of frontal recess cells between male and female.

\begin{tabular}{|c|c|c|c|c|c|c|c|c|}
\hline & & & ale & & nale & & tal & \\
\hline & & No. & $\%$ & No. & $\%$ & No. & $\%$ & value \\
\hline$A N C:$ & Unilateral & 6 & 46.2 & 7 & 53.8 & 13 & 21.7 & 0.871 \\
\hline & Bilateral & 21 & 50.0 & 21 & 50.0 & 42 & 70.0 & \\
\hline & Absent & 3 & 60.0 & 2 & 40.0 & 5 & 8.3 & \\
\hline FC1: & Unilateral & 8 & 42.1 & 11 & 57.9 & 19 & 31.7 & 0.580 \\
\hline & Bilateral & 0 & 0.0 & 0 & 0.0 & 0 & 0.0 & \\
\hline & Absent & 22 & 53.7 & 19 & 46.3 & 41 & 68.3 & \\
\hline$F C 2:$ & Unilateral & 11 & 55.0 & 9 & 45.0 & 20 & 33.3 & 0.542 \\
\hline & Bilateral & 0 & 0.0 & 1 & 100.0 & 1 & 1.7 & \\
\hline & Absent & 19 & 48.7 & 20 & 51.3 & 39 & 65.0 & \\
\hline FC3: & Unilateral & 6 & 75.0 & 2 & 25.0 & 8 & 13.3 & $0.050 *$ \\
\hline & Bilateral & 0 & 0.0 & 4 & 100.0 & 4 & 6.7 & \\
\hline & Absent & 24 & 50.0 & 24 & 50.0 & 48 & 80.0 & \\
\hline FC4: & Unilateral & 2 & 66.7 & 1 & 33.3 & 3 & 5.0 & 0.554 \\
\hline & Bilateral & 0 & 0.0 & 0 & 0.0 & 0 & 0.0 & \\
\hline & Absent & 28 & 49.1 & 29 & 50.9 & 57 & 95.0 & \\
\hline$F B C:$ & Unilateral & 9 & 56.3 & 7 & 43.8 & 16 & 26.7 & 0.076 \\
\hline & Bilateral & 4 & 100.0 & 0 & 0.0 & 4 & 6.7 & \\
\hline & Absent & 17 & 42.5 & 23 & 57.5 & 40 & 66.7 & \\
\hline$S B C:$ & Unilateral & 7 & 50.0 & 7 & 50.0 & 14 & 23.3 & 0.837 \\
\hline & Bilateral & 2 & 66.7 & 1 & 33.3 & 3 & 5.0 & \\
\hline & Absent & 21 & 48.8 & 22 & 51.2 & 43 & 71.7 & \\
\hline SOEC: & Unilateral & 10 & 45.5 & 12 & 54.5 & 22 & 36.7 & 0.866 \\
\hline & Bilateral & 9 & 52.9 & 8 & 47.1 & 17 & 28.3 & \\
\hline & Absent & 11 & 52.4 & 10 & 47.6 & 21 & 35.0 & \\
\hline IFSC: & Single & 13 & 44.8 & 16 & 55.2 & 29 & 48.3 & 0.570 \\
\hline & Multiple & 2 & 40.0 & 3 & 60.0 & 5 & 8.3 & \\
\hline & Absent & 15 & 57.7 & 11 & 42.3 & 26 & 43.3 & \\
\hline
\end{tabular}

Table (15): Association between FBC and other types of frontal recess cells.

\begin{tabular}{|c|c|c|c|c|c|c|c|c|}
\hline & & \multicolumn{6}{|c|}{ FBC } & \multirow{3}{*}{$\begin{array}{c}\quad p- \\
=\text { value }\end{array}$} \\
\hline & & \multicolumn{2}{|c|}{ Unilateral } & \multicolumn{2}{|c|}{ Bilateral } & \multicolumn{2}{|c|}{ Absent } & \\
\hline & & Count & $\begin{array}{l}\text { Row } \\
\mathrm{N} \%\end{array}$ & Count & $\begin{array}{l}\text { Row } \\
\text { N \% }\end{array}$ & Count & $\begin{array}{l}\text { Row } \\
\text { N\% }\end{array}$ & \\
\hline \multirow[t]{3}{*}{$A N C:$} & Unilateral & 3 & 23.1 & 0 & 0.0 & 10 & 76.9 & \multirow[t]{3}{*}{0.663} \\
\hline & Bilateral & 12 & 28.6 & 4 & 9.5 & 26 & 61.9 & \\
\hline & Absent & 1 & 20.0 & 0 & 0.0 & 4 & 80.0 & \\
\hline \multirow[t]{3}{*}{ FC1: } & Unilateral & 4 & 21.1 & 2 & 10.5 & 13 & 68.4 & \multirow[t]{3}{*}{0.618} \\
\hline & Bilateral & 0 & 0.0 & 0 & 0.0 & 0 & 0.0 & \\
\hline & Absent & 12 & 29.3 & 2 & 4.9 & 27 & 65.9 & \\
\hline \multirow[t]{3}{*}{ FC2: } & Unilateral & 4 & 20.0 & 3 & 15.0 & 13 & 65.0 & \multirow[t]{3}{*}{0.385} \\
\hline & Bilateral & 0 & 0.0 & 0 & 0.0 & 1 & 100.0 & \\
\hline & Absent & 12 & 30.8 & 1 & 2.6 & 26 & 66.7 & \\
\hline \multirow[t]{3}{*}{ FC3: } & Unilateral & 2 & 25.0 & 0 & 0.0 & 6 & 75.0 & \multirow[t]{3}{*}{0.713} \\
\hline & Bilateral & 2 & 50.0 & 0 & 0.0 & 2 & 50.0 & \\
\hline & Absent & 12 & 25.0 & 4 & 8.3 & 32 & 66.7 & \\
\hline \multirow[t]{3}{*}{ FC4: } & Unilateral & 2 & 66.7 & 1 & 33.3 & 0 & 0.0 & \multirow[t]{3}{*}{$0.025^{*}$} \\
\hline & Bilateral & 0 & 0.0 & 0 & 0.0 & 0 & 0.0 & \\
\hline & Absent & 14 & 24.6 & 3 & 5.3 & 40 & 70.1 & \\
\hline \multirow[t]{3}{*}{$S B C:$} & Unilateral & 1 & 7.1 & 0 & 0.0 & 13 & 92.9 & \multirow[t]{3}{*}{0.085} \\
\hline & Bilateral & 0 & 0.0 & 0 & 0.0 & 3 & 100.0 & \\
\hline & Absent & 15 & 34.9 & 4 & 9.3 & 24 & 55.8 & \\
\hline \multirow[t]{3}{*}{ SOEC: } & Unilateral & 6 & 27.3 & 1 & 4.5 & 15 & 68.2 & \multirow[t]{3}{*}{0.968} \\
\hline & Bilateral & 5 & 29.4 & 1 & 5.9 & 11 & 64.7 & \\
\hline & Absent & 5 & 23.8 & 2 & 9.5 & 14 & 66.7 & \\
\hline \multirow[t]{3}{*}{ IFSC: } & Single & 8 & 27.6 & 2 & 6.9 & 19 & 65.5 & \multirow[t]{3}{*}{0.961} \\
\hline & Multiple & 1 & 20.0 & 0 & 0.0 & 4 & 80.0 & \\
\hline & Absent & 7 & 26.9 & 2 & 7.7 & 17 & 65.4 & \\
\hline
\end{tabular}




\section{Discussion}

A lot of interest has been generated between researchers as regards the anatomy of frontal sinus and frontal recess. It became evident that frontal recess is a vital area in endoscopic surgical treatment of frontal sinus disease. The current study was conducted to line out ranges of different dimensions of frontal sinus and frontal recess as well as to identify types and prevalence of frontal recess cells which may affect the frontal sinus drainage pathway, or predispose to recurrent sinusitis if not properly dissected in endoscopic sinus surgery. Correlation between different variations was also considered. Dimensions and volume of frontal sinus recorded in the present study showed apparent difference between right and left sides as well as between males and females. They were all higher in the left than the right side (except for the sinus volume which was higher on the right side) but statistically insignificant. Side differences in width, height and depth came in accordance with many studies which reported higher values on the left side $[12,13]$ but disagreed with others in which right side dimensions predominated [7] or no side difference was encountered [14]. This dissimilarity between studies may be contributed to racial difference as most of the studies that showed left sinus dominancy were conducted on Brazilians [13] one was conducted on Turkish population [12], while the one that agreed with the present work was carried out on Indians [15]. Out of the 60 studied population in the present work, $48(80 \%)$ had asymmetrical frontal sinuses based on the asymmetrical index suggested by Suman et al. [8]. This comes in agreement with the one conducted by Rubira-Bullen et al. [16] who investigated 158 plain facial radiographs and $88(60.7 \%)$ were asymmetrical. In contrast, the study of David et al. [17] revealed that $16(32 \%)$ out of 50 individuals had asymmetrical sinuses, and that conducted by Verma et al. [18] stated that only $18(22.5 \%)$ out of 80 subjects had asymmetric pattern of frontal sinus. Regarding sex difference, all measurements in the present thesis were higher among males than females, but only significant for height, depth and volume ( $p=0.04,0.03$ and 0.019 respectively). This result correlates with nearly all recent studies which recorded higher frontal sinus dimensions among males $[12,15,18]$. Comparing measurements between age groups described in the present thesis, highest values of right side dimensions were observed in group 2 (age from 31 to 50 years) while highest values of left side dimensions were observed in group 1 (age from 20 to 30) except for the left depth. Group 3 (age above 50 years) had the highest value of left depth and the lowest value of left height. However, no significant difference was encountered between age groups except for the right width $(p=0.027)$ between group 2 and 3 . These age differences greatly agree with those reported by Tatlisumak et al. [19] and Tatlisumak et al. [12] but disagree with Rubira-Bullen et al. [16] and Michel et al. [20]. Results of the present study revealed that A-P length of FR was slightly higher among females than males and tended to increase with age on the right side while on the left side it had the lowest value in group 2. Higher mean values were encountered in the left than the right side with positive correlation between the two sides. Although little information concerning A-P length of FR is available, Jacobs et al. [21] pointed that this dimension is vital for successful endoscopic surgery especially in extended procedures that require additional bone resection. A limitation of studying this dimension is that it doesn't reflect the course, width, and depth of FSOT. However, Park et al. [9] stated that A-P length of FR could be one of the important information for building a 3-dimensional picture of the FSOT. Wormald [22] used the ANC as the key around which the anatomy of FR is built and assumed that a large ANC reduces the thickness of the Frontal Beak (FB). Building their work on this relation, Park et al. [9] expected that decreased FB thickness caused by large ANC volume will consequently lead to increased A-P length of FR, so that resection of the ANC will allow for wide surgical exposure of the FR. The current study showed no correlation between AP length and volume of ANC in contrast to the work of Jacobs et al. [21] who found a positive correlation between A-P length and agger nasi cell size in 31 out of 40 sides, and Park et al. [9] who reported that the volume of the ANC showed a weak positive correlation with the A-P length of the FR in 182 out of 190 sides $(r=0.41, p<0.001)$. This discordance with the latter two studies may be since they studied patients with chronic sinusitis which may alter the normal FR anatomy. The frontal sinus anterior table thickness in this study showed higher mean values on the left than the right side, and among males than females though no statistical significance was encountered. Between age groups, the highest values were reported in group 2 (age from 31 to 50 years) and the lowest were present in group 3 (age above 50 years) probably due to increased bone resorption with age. Differences between age groups were not significant except for the right width between groups 2 and 3 . The side difference disagrees with results of SahlstrandJohnson et al. who stated equal mean values of right and left sides, and no significant difference 
between the sexes. The frontal sinus anterior table thickness was important since one upon performing an ultrasound examination of the frontal sinuses usually holds the ultrasound probe against this area, so the thickness of this area affects the ultrasound wave of the Doppler equipment. This may help further development of clinically applicable Doppler equipment for staging a sinus infection [10].

\section{Conclusion:}

Awareness of frontal sinus dimensions frontal recess cells variations among Egyptians should be taken in consideration in safe frontal endoscopic surgery.

\section{Conflicts of interest:}

Nil had been displayed by all authors.

\section{References}

1- WORMALD P.J., HOSEMAN W., CALLEJAS C., et al.: The international frontal sinus anatomy classification (IFAC) and classification of the extent of endoscopic frontal sinus surgery (EFSS). Int. Forum. Allergy Rhinol., 6: 677-96, 2016.

2- KUHN F.A. and JAVER A.R.: Primary endoscopic management of the frontal sinus. Otolaryngologic clinics of North America, 34 (10): p. 69-75, 2001.

3- CAMARGO J.R., DARUGE E., PRADO F.B., CARIA P.H., ALVES M.C., SILVA R.F., et al.: The frontal sinus morphology in radiographs of Brazilian subjects; its forensic importance. Braz J. Morphol. Sci., 24: 239-43, 2007.

4- TANG J.P., HU D.Y., JIANG F.H. and YU X.J.: Assessing forensic applications of the frontal sinus in a Chinese Han population. Forensic Sci. Int., 183: 104.e-e3, 2009.

5- KIRK N.J., WOOD R.E. and GOLDSTEIN M.: Skeletal identification using the frontal sinus region: A retrospective study of 39 cases. J. Forensic. Sci., 47: 318-23, 2002.

6- MAHMUTO GLU A.S., ÇELEBI I., AKDANA B., BANKAOĞLU M., ÇAKMAKÇI E., ÇELIKOYAR M.M. and BASSAK M.: Computed tomographic analysis of frontal sinus drainage pathway variations and frontal rhinosinusitis. J. Craniofac. Surg., 26: 87-90, 2015.

7- BELALDAVAR C., KOTRASHETTI V.S., HALLIKERIMATH S.R. and KALE A.D.: Assessment of frontal sinus dimensions to determine sexual dimorphism among Indian adults. J. Forensic Dent. Sci., 6: 25-30, 2014.

8- SUMAN J.L., JAISANGHAR N., ELANGOVAN S., MAHABOOB N., SENTHIKUMAR B., YOITHAPPRABHUNATH T.R. and SRICHINTHU K.K.: Configuration of frontal sinuses: A forensic perspective. Journal of Pharmacy \& Bioallied Sciences, 8 (Suppl 1): S90-S95, 2016.

9- PARK S.S., YOON B.N., CHO K.S. and ROH H.J.: Pneumatization pattern of the frontal recess: Relationship of the anterior-to-posterior length of frontal isthmus and/or frontal recess with the volume of agger nasi cell. CEO, 3 (2): 76-83, 2010.
10- SAHLSTRAND-JOHNSON P., JANNERT M., STRÖMBECK A. and ABUL-KASIM K.: Computed tomography measurements of different dimensions of maxillary and frontal sinuses. BMC Medical Imaging, 11: 8, 2011.

11-LEE W.T., KUHN F.A. and CITARDI M.J.: 3D computed tomographic analysis of frontal recess anatomy in patients without frontal sinusitis. Otolaryngology-Head and Neck Surgery, 131 (3): 164-73, 2004.

12- TATLISUMAK E., ASIRDIZER M., BORA A., HEKIMOGLU Y., ETLI Y., GUMUS O. and KESKIN S.: The effects of gender and age on forensic personal identification from frontal sinus in a Turkish population. Saudi Med. J., 38 (1): 41-7, 2017.

13- ASLIER N.G., KARABAY N., ZEYBEK G., KESKINO GLU P., KIRAY A., SÜTAY S. and ECEVIT M.C.: Computed Tomographic analysis: The effects of frontal recess morphology and the presence of anatomical variations on frontal sinus pneumatization. J. Craniofac. Surg., 28: 256-61, 2017.

14- EBOH D.E., OGBEIDE O.U. and IVWIGHREN T.: Radiographic anthropometric study of frontal sinus for sex determination in Benin city, South-South Nigeria. J. Forensic. Dent. Sci., 9: 31-5, 2017.

15- PANSHEWDIKAR P.N., THAKRE G.D., JOSHI D.S., BAIG M.M. and DESHMUKH A.G.: Morphometric sexual dimorphism of frontal air sinus: A CT study. IOSR-JDMS; 16 (6): 28-31, 2017.

16-RUBIRA-BULLEN I.R.F., RUBIRA C.M.F., SARMENTO V.A. and AZEVEDO R.A.: Frontal sinus size on facial plain radiographs. J. Morphol. Sci., 27 (2): 77-81, 2010.

17- DAVID M.P. and SAXENA R.: Use of frontal sinus and nasal septum patterns as an aid in personal identification: A digital radiographic pilot study. J. Forensic Denti. Sci., 2 (2): 77-80, 2010.

18- VERMA K., NAHAR P., SINGH M.P., MATHUR H. and BHUVANESHWARI S.: Use of frontal sinus and nasal septum pattern as an aid in personal identification and determination of gender: A radiographic study. Journal of Clinical and Diagnostic Research, 11 (1): 71-4, 2017.

19-TATLISUMAK E., OVALI G.Y., ASIRDIZER M., ASLAN A., OZYURT B., BAYINDIR P. and TARHAN S.: CT study on morphometry of frontal sinus. Neuroanatomy, 5: 163, 2006.

20- MICHEL J., PAGANELLI A., VAROQUAUX A., PIERCECCHI-MARTI M.D., ADALIAN P., LEONETTI G, and DESSI P.: Determination of sex: Interest of frontal sinus 3D reconstructions. J. Forensic Sci., 60 (2): 269 73, 2015.

21- JACOBS J.B., LEBOWITZ R.A., SORIN A., HARIRI S. and HOLLIDAY R.: Pre-operative sagittal CT evaluation of the frontal recess. Am. J. Rhinol., 14 (1): 33-7, 2000.

22- WORMALD P.J.: The agger nasi cell: The key to understanding the anatomy of the frontal recess. Otolaryngol. Head Neck Surg., 129: 497-507, 2003. 


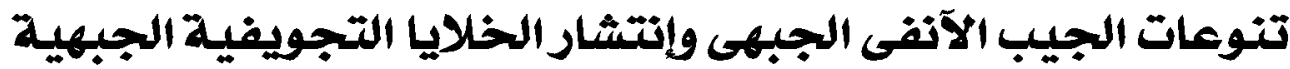

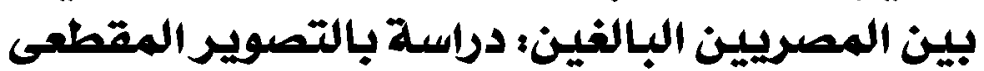

الخلفية: غالباً ما تعتبر الجيوب الآنفية الجبهية المنطقة الآكثر تحدياً للإقتراب منها فى جراحة الجيوب الآنفية بالمناظير الوظيفية. وقد تم الإبلاغ عن إختلافات كبيرة فى شكل وقدرة وتماثل الجيوب الآنفية الجبهية.

هدف الدراسة: لتوفير فهم آفضل لمقاييس الجيوب الآنفية الجبهية والتغيرات التشريحية الخلايا التجويفية الجبهية المحددة وإنتشارها بين البالغين المصريين.

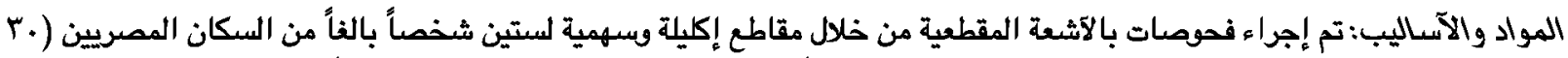

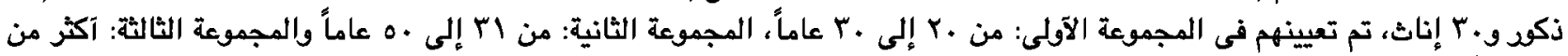
. م عاماً) لإظهار تشريح الجيوب الآنفية الجبهية.

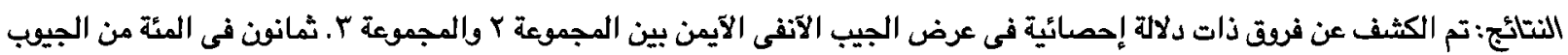

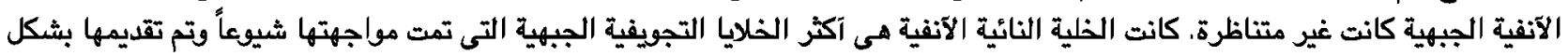

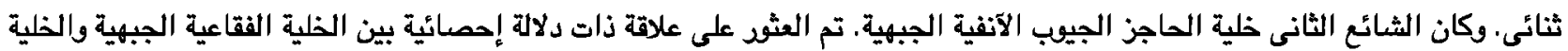

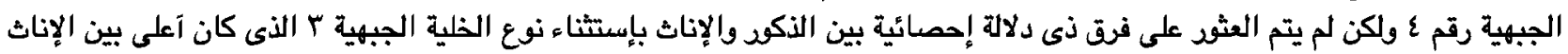

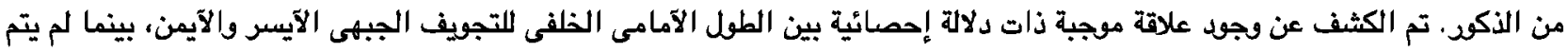
العثو على علاقة ذات دلالة إحصائية بين الطول الآمامى الخلفى اللتجويف الجبهى وحجم الخلايا النائية الآنفية. الإستتاج: الوعى بآبعاد الجيوب الآنفية الجبهية والخلايا التجويفية الجيهية يجب آن تؤخذ فى الإعتبار فى جراحة المناظير الجيهية الآمنة. 